\title{
Association between polymorphisms in SLC30A8, HHEX, CDKN2A/B, IGF2BP2, FTO, WFS1, CDKAL1, KCNQ1 and type 2 diabetes in the Korean population
}

\author{
Yong-Ho Lee $\cdot$ Eun Seok Kang · So Hun Kim · Seung Jin Han · Chul Hoon Kim • \\ Hyeong Jin Kim • Chul Woo Ahn · Bong Soo Cha • Moonsuk Nam • \\ Chung Mo Nam · Hyun Chul Lee
}

Received: 6 August 2008/Accepted: 16 October 2008/Published online: 11 November 2008

(C) The Japan Society of Human Genetics and Springer 2008

\begin{abstract}
According to recent genome-wide association studies, a number of single nucleotide polymorphisms (SNPs) are reported to be associated with type 2 diabetes mellitus (T2DM). The aim of the present study was to investigate the association among the polymorphisms of SLC30A8, HHEX, CDKN2A/B, IGF2BP2, FTO, WFS1, $C D K A L 1$ and $K C N Q 1$ and the risk of T2DM in the Korean population. This study was based on a multicenter casecontrol study, including 908 patients with T2DM and 502 non-diabetic controls. We genotyped rs13266634, rs1111875, rs10811661, rs4402960, rs8050136, rs734312, rs7754840 and rs2237892 and measured the body weight, body mass index and fasting plasma glucose in all patients and controls. The strongest association was found in a
\end{abstract}

Y. Lee and E. S. Kang contributed equally to this work.

Y.-H. Lee · E. S. Kang - S. J. Han · C. W. Ahn ·

B. S. Cha $\cdot$ H. C. Lee $(\square)$

Department of Internal Medicine,

Yonsei University College of Medicine,

134 Shinchon-Dong Seodaemun-Gu,

Seoul 120-752, South Korea

e-mail: endohclee@yuhs.ac

E. S. Kang - C. H. Kim - C. W. Ahn · B. S. Cha · H. C. Lee Brain Korea 21 Project for Medical Science,

Yonsei University College of Medicine,

Seoul, South Korea

E. S. Kang - C. W. Ahn - B. S. Cha - H. C. Lee

Institute of Endocrine Research,

Yonsei University College of Medicine,

Seoul, South Korea

S. H. Kim - M. Nam

Department of Internal Medicine,

Inha University College of Medicine,

Inchon, South Korea variant of $C D K A L 1$ [rs7754840, odds ratio $(\mathrm{OR})=1.77$, $\left.95 \% \mathrm{CI}=1.50-2.10, p=5.0 \times 10^{-11}\right]$. The $\mathrm{G}$ allele of rs1111875 $(\mathrm{OR}=1.43,95 \% \mathrm{CI}=1.18-1.72, p=1.8 \times$ $\left.10^{-4}\right)$ in $\left.H H E X\right)$, the $\mathrm{T}$ allele of rs10811661 $(\mathrm{OR}=1.47$, $\left.95 \% \mathrm{CI}=1.23-1.75, p=2.1 \times 10^{-5}\right)$ in $\left.C D K N 2 A / B\right)$ and the $\mathrm{C}$ allele of rs2237892 (OR $=1.31,95 \% \mathrm{CI}=1.10$ $1.56, p=0.003)$ in $K C N Q 1$ showed significant associations with T2DM. Rs13266634 $(\mathrm{OR}=1.19,95 \% \mathrm{CI}=$ $1.00-1.42, p=0.045)$ in SLC 3OA8 showed a nominal association with the risk of T2DM, whereas SNPs in $I G F 2 B P 2, F T O$ and WFS1 were not associated. In conclusion, we have shown that SNPs in $H H E X, C D K N 2 A / B$, CDKAL1, KCNQ1 and SLC3OA8 confer a risk of T2DM in the Korean population.

\section{H. Kim}

Department of Pharmacology,

Yonsei University College of Medicine,

Seoul, South Korea

\section{H. J. Kim}

Department of Internal Medicine,

Kwandong University College of Medicine,

Gangneung, South Korea

C. M. Nam

Department of Preventive Medicine and Public Health,

Yonsei University College of Medicine,

Seoul, South Korea 
Keywords Type 2 diabetes - SLC3OA8 - HHEX . $C D K N 2 A / B \cdot C D K A L 1 \cdot K C N Q 1 \cdot \mathrm{SNP}$.

Genetic association

$\begin{array}{ll}\text { Abbreviations } \\ \text { SNP } & \text { Single nucleotide polymorphisms } \\ \text { T2DM } & \text { Type } 2 \text { diabetes mellitus } \\ \text { OR } & \text { Odds ratio } \\ \text { CI } & \text { Confidence interval } \\ \text { BMI } & \text { Body mass index } \\ \text { FPG } & \text { Fasting plasma glucose }\end{array}$

\section{Introduction}

Type 2 diabetes mellitus (T2DM) is a chronic metabolic disorder characterized by hyperglycemia, variable degrees of insulin resistance, impaired insulin secretion and increased hepatic glucose production. The total global number of people with diabetes was estimated to be over 189 million in the year 2003 (Zimmet et al. 2003) and is expected to rise more rapidly in the future as obesity increases, the population becomes older and the physical activity levels of most people decrease.

In addition to the environmental factors mentioned above, genetic components are obviously associated with the development of T2DM. One of the earliest T2DM susceptibility genes published was Calpain 10 (CAPN10) (Hanis et al. 1996), followed by peroxisome proliferatoractivated receptor gamma (PPARG) (Altshuler et al. 2000), potassium inwardly rectifying channel, subfamily J, member 11 (KCNJ11) (Gloyn et al. 2003) and transcription factor 7-like 2 (TCF7L2) (Grant et al. 2006), polymorphisms of which were discovered to be strongly associated with T2DM in 2006. Since 2007, new genetic loci have been identified as T2DM susceptibility genes by genomewide association scanning, including: loci near hematopoietically expressed homeobox (HHEX)-insulindegrading enzyme (IDE), cyclin-dependent kinase 5 (CDK5) regulatory subunit-associated protein 1-like 1 $(C D K A L 1)$, fat mass and obesity associated (FTO), cyclindependent kinase inhibitor 2A/B $(C D K N 2 A / B)$, zinc transporter-8 (ZnT-8) solute carrier family 30 member 8 gene (SLC30A8), insulin-like growth factor 2 mRNAbinding protein 2 (IGF2BP2) and KCNQ1 (Saxena et al. 2007; Scott et al. 2007; Sladek et al. 2007; Steinthorsdottir et al. 2007; Zeggini et al. 2007; Yasuda et al. 2008).

However, it has recently been reported that there are significant differences in the contribution of known single nucleotide polymorphisms (SNPs) in susceptibility genes among various ethnic populations. Therefore, replication studies in other populations are important. We investigated the association between known SNPs in several T2DM candidate genes and the prevalence of T2DM in the Korean population.

\section{Research design and methods}

Subjects and measurements

The studied population included 502 non-diabetic control subjects and 908 unrelated Korean type 2 diabetic patients recruited from the outpatient clinics of Yonsei Medical University Hospital and Inha Medical University Hospital. Diabetes was diagnosed according to the criteria of the American Diabetes Association. Patients were excluded if they were positive for the glutamic acid decarboxylase antibody. The non-diabetic control subjects comprised the normoglycemic population from health check-up subjects with no history of severe metabolic or infectious disease and from regular follow-up patients from the outpatient clinics of the Diabetes Center of Yonsei University Severance Hospital and the Inha Medical University Hospital. Blood samples were collected after an overnight fast, and the FPG level was determined by an enzymatic colorimetric assay. The HbA1c values were determined by highperformance liquid chromatography (Variant II, GREENCROSS, Seoul, Korea). The protocol of this study was approved by the ethics committee of the Yonsei University College of Medicine. All patients and controls received adequate information about this study and gave written informed consent.

DNA extraction and genotyping

Genomic DNA was isolated from peripheral blood lymphocytes. We selected SLC30A8 rs13266634, HHEX rs1111875, CDKN2A/B rs10811661, IGF2BP2 rs4402960, FTO rs8050136, WFS1 rs734312, CDKAL1 rs7754840 and $K C N Q 1$ rs2237892 because their minor allele frequencies (MAF) are relatively high $(>10 \%)$ and are reported to be associated with T2DM in Asian populations (Kang et al. 2008a, b). Because rs 7754840 and rs 10946398 in CDKAL1 were in complete linkage $\left(D^{\prime}=1, r^{2}=1\right)$ in our 200 samples and in the study by Palmer et al. (2008), we only genotyped rs7754840. As regarding WFS1, we genotyped rs734312 among four SNPs (rs734312, rs752854, rs6446482 and rs10010131) according to our pilot data of 88 samples that MAF of rs752854, rs6446482 and rs10010131 were $0,1.1$ and $0 \%$, respectively. Genotyping was performed according to the processes as previously described (Kang et al. 2008a, b). TaqMan PCR Assay ID was C2684958_10 for rs13266634 in SLC30A8, C11214581_10 for rs1111875 in HHEX, C31288917_10 
for rs10811661 in $C D K N 2 A / B, \quad$ C2165199_10 for rs4402960 in IGF2BP2, C2031259_10 for rs8050136 in FTO, C2401729_1 for rs734312 in WFS1 and C29246232_10 for rs7754840 in CDKAL1. KCNQ1 rs2237892 genotype was assayed by single base primer extension assay using an ABI PRISM SNaPShot Multiplex kit (ABI, Foster City, CA), according to manufacturer's instructions.

Forty-eight (3.4\%) duplicate samples and negative controls were included to ensure the accuracy of genotyping, and $100 \%$ of the duplicates replicated the original genotype. The rates of successful genotyping were $100 \%$ (rs13266634), 96.2\% (rs1111875 and rs10811661), 96.6\% (rs4402960), 99.2\% (rs8050136), 99.7\% (rs734312), 99.1\% (rs7754840) and $98.8 \%$ (rs2237892), respectively.

\section{Statistical analyses}

The genotype frequencies were tested for Hardy-Weinberg equilibrium using the $\chi^{2}$ test. All continuous variables were expressed as the mean \pm standard deviation (SD). Student's $t$ test was used to compare the continuous variables between the T2DM and non-diabetic control groups. Pearson's $\chi^{2}$ test was used to evaluate the difference in the prevalence of T2DM among genotypes. One-way ANOVA was used to compare continuous variables among the three genotypes. For these calculations, patients with the nonrisk allele were denoted as 0 , heterozygotes were denoted as 1 , and patients homozygous for the risk allele were denoted as 2. In order to control for age, sex and BMI effects, multivariable logistic regression tests were used, and odds ratio (OR) and 95\% confidence intervals (CI) were calculated. We analyzed the data using two-sided $p$ values, and a $p$ value less than 0.05 was considered statistically significant. Statistical analyses were performed using SPSS for Windows software (version 12.0; SPSS, Chicago, IL). Power calculations were performed using PASS software version 2005 (NCSS statistical Software, Kaysville, UT).

\section{Results}

Genotyping of eight representative SNPs from T2DM susceptibility genes were replicated in 502 non-diabetic control subjects and 908 unrelated type 2 diabetic patients from the Korean population. The baseline clinical and biochemical characteristics of the subjects are shown in Table 1. The mean age, body mass index (BMI), weight and fasting plasma glucose (FPG) level were $55.0 \pm 9.4$ years, $22.1 \pm 3.0 \mathrm{~kg} / \mathrm{m}^{2}, 58.7 \pm 9.4 \mathrm{~kg}$ and $5.1 \pm 1.0 \mathrm{mmol} / \mathrm{l}$, respectively. A slightly higher proportion of females (51.6\%) was observed in the case group than in the control
Table 1 Clinical characteristics of the study population

\begin{tabular}{lllr}
\hline & Control & T2DM & $p$ value \\
\hline$N$ (\% female) & $502(46.4 \%)$ & $908(51.6 \%)$ & $0.063^{*}$ \\
Age at diagnosis (years) & NA & $47.8 \pm 10.8$ & \\
Age at examination (years) & $55.0 \pm 9.4$ & $58.2 \pm 11.1$ & $<0.001$ \\
BMI $\left(\mathrm{kg} / \mathrm{m}^{2}\right)$ & $22.1 \pm 3.0$ & $24.3 \pm 3.2$ & $<0.001$ \\
Weight $(\mathrm{kg})$ & $58.7 \pm 9.4$ & $63.6 \pm 10.8$ & $<0.001$ \\
FPG $(\mathrm{mmol} / \mathrm{l})$ & $5.1 \pm 1.0$ & $7.5 \pm 2.2$ & $<0.001$ \\
\hline
\end{tabular}

Data presented as means \pm SD or $N(\%)$ unless otherwise indicated. $p$ values were calculated from $t$ tests

$N A$ not available, BMI body mass index

* $p$ values assessed by Pearson's $\chi^{2}$ test

groups (46.4\%), which may be due to a participation bias. Diabetic patients were older than non-diabetic control subjects $(58.2 \pm 11.1$ vs. $55.0 \pm 9.4, p<0.001)$. The mean body weight and BMI between the two groups were significantly different $(63.6 \pm 10.8$ vs. $58.7 \pm 9.4 \mathrm{~kg}$, $p<0.001 ; 24.3 \pm 3.2$ vs. $22.1 \pm 3.0 \mathrm{~kg} / \mathrm{m}^{2}, p<0.001$, respectively). The FPG level was also significantly higher in the diabetic group subjects compared to normal control subjects $(7.5 \pm 2.2$ vs. $5.1 \pm 1.0, p<0.001)$.

The genotype and allele frequencies of T2DM susceptibility gene SNPs in type 2 diabetic patients and control subjects are shown in Table 2. Genotype distributions were in agreement with Hardy-Weinberg equilibrium. Among eight SNPs, rs1111875 in HHEX, rs10811661 in CDKN2A/ $B$, rs7754840 in $C D K A L 1$ and rs2237892 in $K C N Q 1$ locus were significantly associated with T2DM. The observed associations between T2DM and two SNPs - rs1111875 and rs7754840 — were strengthened after adjusting for age, sex and BMI using multivariable logistic regression analysis. The strongest association was found in the variant in $C D K A L 1 \quad$ rs7754840 $\quad(\mathrm{OR}=1.77, \quad$ adjusted $p=4.6 \times 10^{-10}$ ). However, rs13266634 in the SLC30A8 gene locus showed nominal association with T2DM $(\mathrm{OR}=1.19$, adjusted $p=0.045)$, and no significant associations with $\mathrm{T} 2 \mathrm{DM}$ were observed in IGF2BP2 rs4402960, FTO rs8050136 and WFS1 rs734312 from our study population (adjusted $p=0.123,0.347$ and 0.362 , respectively). The rs13266634, rs10811661 and rs2237892 risk alleles were major alleles, while the other risk alleles were minor alleles in our population, consistent with previous reports in European populations (Scott et al. 2007; Saxena et al. 2007; Zeggini et al. 2007). Interestingly, the $\mathrm{G}$ allele of rs1111875, which was reported to be a major allele in Caucasian ethnic groups, was revealed as a minor allele in our study; this is supported by similar results from Japanese populations (Furukawa et al. 2008; Horikoshi et al. 2007; Omori et al. 2008).

For each SNP proven to be a possible T2DM-susceptible variant according to our study, we further analyzed the 


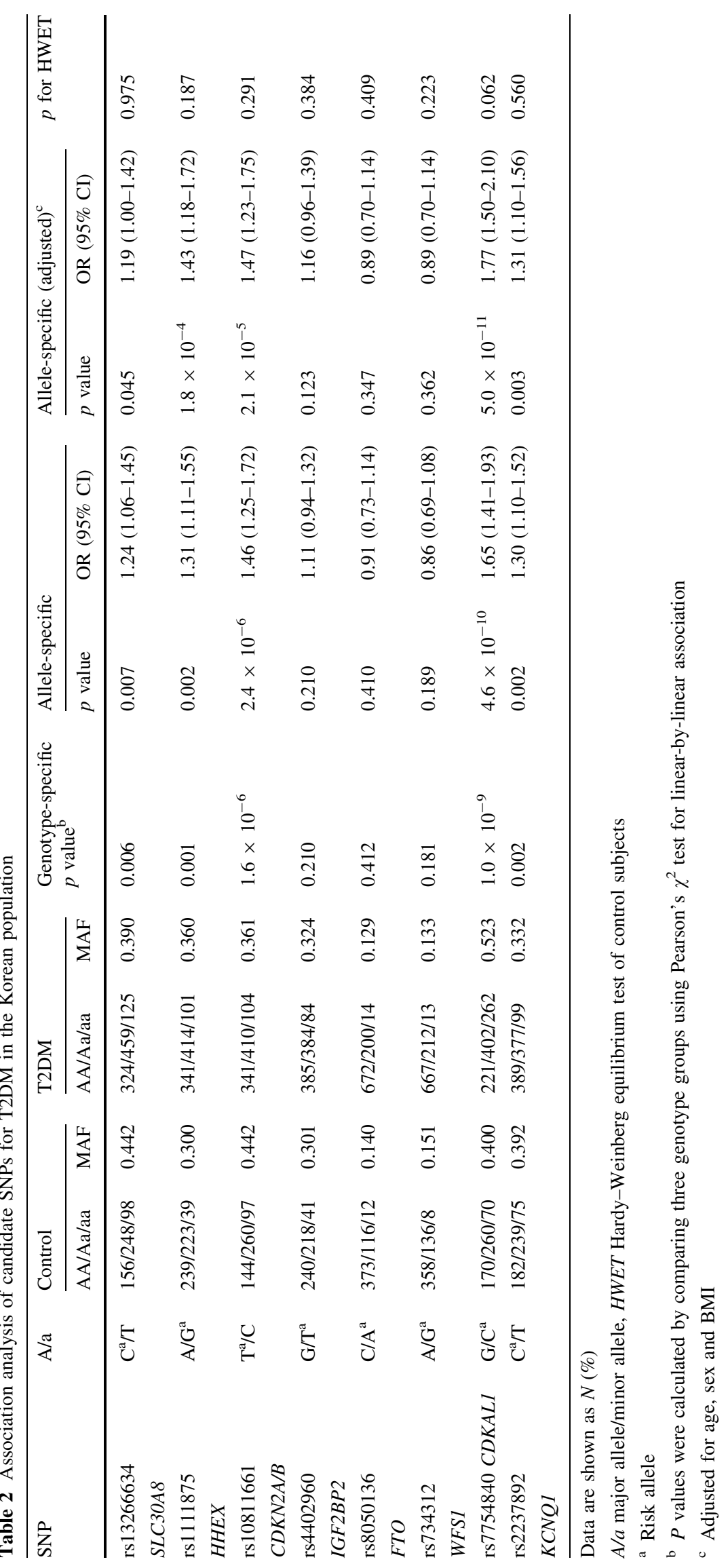


effect of genotypes under three different genetic models (Table 3). The $\mathrm{C} / \mathrm{C}$ and $\mathrm{C} / \mathrm{T}$ genotypes of SLC30A8 conferred a significantly increased risk for T2DM compared to the T/T genotype in the additive or dominant model. The $\mathrm{G}$ allele of $H H E X$ rs1111875, the $\mathrm{T}$ allele of $C D K N 2 A / B$ rs10811661 and the $\mathrm{C}$ allele of $C D K A L 1$ rs7754840 all were associated with an increased prevalence of T2DM in all three genetic models. Only individuals with the CC genotype of rs2237892 in the recessive model had a higher risk of T2DM. No association was observed in any genetic models for rs4402960, rs8050136 and rs734312. There was no significant association between the genotypes of eight SNPs and clinical characteristics (age, sex and BMI) in the type 2 diabetic patients (data not shown).

\section{Discussion}

The identification of a new gene for polygenic T2DM was recently achieved by genome-wide SNP assays. Among several SNPs associated with susceptibility to T2DM, polymorphisms in SLC3OA8, HHEX, CDKN2A/B, IGF2BP2,
FTO, WFS1, CDKAL1 and KCNQ1 were first reported by several studies performed in European and Asian populations (Scott et al. 2007; Sladek et al. 2007; Saxena et al. 2007; Zeggini et al. 2007; Sandhu et al. 2007; Yasuda et al. 2008). These genetic variants have been repetitively confirmed by multiple studies in various populations (Horikoshi et al. 2007; Steinthorsdottir et al. 2007; Omori et al. 2008; $\mathrm{Ng}$ et al. 2008). Nevertheless, the effects of genetic variants on the risk of T2DM are somewhat inconsistent among different ethnic groups. For example, Furukawa et al. (2008) reported a nominal association between rs13266634, a nonsynonymous SNP in SLC30A8, and T2DM in a Japanese population, while Horikoshi et al. (2007) reported that there was no significant association in another Japanese population.

In this case-control study, we demonstrated the association between the polymorphisms of the SLC30A8, HHEX, $C D K N 2 A / B, C D K A L 1$ and $K C N Q 1$ genes and the prevalence of T2DM in Korean subjects. According to our results, the overall risk allele frequencies of those SNPs were significantly different between the Korean and other non-Asian ethnic groups. The frequency of risk allele $\mathrm{C}$ in

Table 3 Effects of susceptible gene genotypes on the risk of T2DM under different genetic models

\begin{tabular}{|c|c|c|c|c|c|c|c|}
\hline & & \multicolumn{2}{|l|}{ Additive model } & \multicolumn{2}{|l|}{ Dominant model } & \multicolumn{2}{|l|}{ Recessive model } \\
\hline & & OR $(95 \% \mathrm{CI})$ & $p$ value & OR $(95 \% \mathrm{CI})$ & $p$ value & OR $(95 \% \mathrm{CI})$ & $p$ value \\
\hline rs 13266634 & $\mathrm{~T} / \mathrm{T}$ & & & & & & \\
\hline \multirow[t]{2}{*}{ SLC $30 A 8$} & $\mathrm{C} / \mathrm{T}$ & $1.45(1.07-1.97)$ & 0.017 & $1.52(1.14-2.03)$ & 0.005 & $1.23(0.98-1.55)$ & 0.080 \\
\hline & $\mathrm{C} / \mathrm{C}$ & $1.63(1.18-2.26)$ & 0.003 & & & & \\
\hline rs1111875 & $\mathrm{A} / \mathrm{A}$ & & & & & & \\
\hline \multirow[t]{2}{*}{ HHEX } & $\mathrm{A} / \mathrm{G}$ & $1.30(1.03-1.64)$ & 0.026 & $1.38(1.10-1.72)$ & 0.005 & $1.59(1.08-2.33)$ & 0.019 \\
\hline & $\mathrm{G} / \mathrm{G}$ & $1.82(1.21-2.72)$ & 0.004 & & & & \\
\hline rs10811661 & $\mathrm{C} / \mathrm{C}$ & & & & & & \\
\hline \multirow[t]{2}{*}{$C D K N 2 A / B$} & $\mathrm{C} / \mathrm{T}$ & $1.47(1.07-2.02)$ & 0.017 & $1.73(1.28-2.35)$ & $3.2 \times 10^{-4}$ & $1.65(1.30-2.09)$ & $3.6 \times 10^{-5}$ \\
\hline & $\mathrm{T} / \mathrm{T}$ & $2.21(1.58-3.10)$ & $3.5 \times 10^{-6}$ & & & & \\
\hline rs4402960 & $\mathrm{G} / \mathrm{G}$ & & & & & & \\
\hline \multirow[t]{2}{*}{$I G F 2 B P 2$} & $\mathrm{G} / \mathrm{T}$ & $1.10(0.87-1.38)$ & 0.443 & $1.13(0.90-1.41)$ & 0.309 & $1.22(0.83-1.80)$ & 0.332 \\
\hline & $\mathrm{T} / \mathrm{T}$ & $1.28(0.85-1.92)$ & 0.266 & & & & \\
\hline rs8050136 & $\mathrm{C} / \mathrm{C}$ & & & & & & \\
\hline \multirow[t]{2}{*}{ FTO } & $\mathrm{C} / \mathrm{A}$ & $0.957(0.74-1.24)$ & 0.742 & $0.928(0.72-1.20)$ & 0.562 & $0.654(0.30-1.43)$ & 0.282 \\
\hline & $\mathrm{A} / \mathrm{A}$ & $0.648(0.30-1.42)$ & 0.272 & & & & \\
\hline rs734312 & $\mathrm{A} / \mathrm{A}$ & & & & & & \\
\hline \multirow[t]{2}{*}{ WFS1 } & $\mathrm{A} / \mathrm{G}$ & $0.837(0.65-1.08)$ & 0.163 & $0.839(0.66-1.07)$ & 0.160 & $0.913(0.38-2.22)$ & 0.841 \\
\hline & $\mathrm{G} / \mathrm{G}$ & $0.872(0.36-2.12)$ & 0.763 & & & & \\
\hline \multirow[t]{3}{*}{ rs7754840 CDKAL1 } & $\mathrm{G} / \mathrm{G}$ & & & & & & \\
\hline & $\mathrm{G} / \mathrm{C}$ & $1.19(0.92-1.53)$ & 0.180 & $1.55(1.22-1.97)$ & $3.3 \times 10^{-4}$ & $2.58(1.93-3.46)$ & $6.4 \times 10^{-11}$ \\
\hline & $\mathrm{C} / \mathrm{C}$ & $2.88(2.07-4.01)$ & $1.9 \times 10^{-10}$ & & & & \\
\hline rs2237892 & $\mathrm{T} / \mathrm{T}$ & & & & & & \\
\hline \multirow[t]{2}{*}{$K C N Q 1$} & $\mathrm{~T} / \mathrm{C}$ & $1.20(0.85-1.68)$ & 0.306 & $1.38(0.998-1.90)$ & 0.051 & $1.41(1.12-1.77)$ & 0.003 \\
\hline & $\mathrm{C} / \mathrm{C}$ & $1.62(1.14-2.29)$ & 0.006 & & & & \\
\hline
\end{tabular}


rs13266634 from our study (55.8\%) was lower than those reported in European or African populations (69.9-97.1\%) (Sladek et al. 2007; Steinthorsdottir et al. 2007). There were also differences in the frequencies of risk alleles in rs1111875, rs10811661, rs8050136 and rs734312. For rs1111875, the risk allele $G$ was a minor allele in Asian subjects, including our group, while the allele $G$ was revealed as a major allele in European populations (Saxena et al. 2007; Scott et al. 2007; Sladek et al. 2007; Palmer et al. 2008); for rs10811661, rs8050136 and rs734312, the Korean population showed much lower MAF compared to the non-Asian groups. These significant differences in risk allele frequencies across ethnic groups indicate that the genetic variations of T2DM susceptibility genes are diversely distributed among different populations.

In our study, each SNP in the HHEX, CDKN2A/B, $C D K A L 1$ and $K C N Q 1$ genes showed a significant association with T2DM. The adjusted allele-specific OR value of rs1111875 (1.43) was similar to that of Japanese groups (1.30-1.42) (Furukawa et al. 2008; Horikoshi et al. 2007; Omori et al. 2008), but higher than that reported from white populations (1.10-1.15) (Saxena et al. 2007; Scott et al. 2007; Sladek et al. 2007). The HHEX gene product is known to act as both a transcription activator and repressor required for the development of the pancreas, liver and blood vessels and is also a target of the $\mathrm{Wnt} / \beta$-catenin signaling pathway (McLin et al. 2007; Foley and Mercola 2005). Since SNP rs1111875 is located near the outside of an HHEX exon, it does not change the amino acid sequence, indicating that further study of the biological function of this SNP is necessary.

Furthermore, we observed considerably higher ORs of rs10811661 in $C D K N 2 A / B$ locus (1.47) and rs7754840 in $C D K A L 1$ locus (1.77) than those found in other Asian or European populations (1.16-1.37) (Sladek et al. 2007; Saxena et al. 2007; Scott et al. 2007; Horikoshi et al. 2007; $\mathrm{Ng}$ et al. 2008). $C D K N 2 A / B$ is a tumor suppressor gene that plays an important role in tumorigenesis and aging (Kim and Sharpless 2006). In addition to its function in cell proliferation and apoptosis, $C D K N 2 A / B$ has recently been reported to be expressed in islets as well as vascular endothelial cells and is affected by hyperglycemia and oxidative stress (Chen et al. 2007; Scott et al. 2007). The function of $C D K A L 1$ protein is elusive; however, there is a similarity between $C D K A L 1$ and CDK5 regulatory subunitassociated protein 1 (CDK5RAP1), which inhibits CDK5 activity. Considering the findings that inhibition of CDK5 prevented the decrease of insulin gene expression by restoring PDX-1, CDKAL1 may play an important role in CDK5-mediated regulation of beta cell function (Wei et al. 2005; Ubeda et al. 2006).

As regarding $K C N Q 1$, which was recently discovered by the Japanese group (Yasuda et al. 2008), we showed a lower value of OR of 1.31 (95\% CI $=1.10-1.56)$ for rs2237892 than those reported in East Asian populations. KCNQ1 protein is a subunit of the voltage-gated $\mathrm{K}+$ channel (KvLQT1) that is expressed in the pancreas as well as cardiac muscles. Modulation of membrane potentials in beta cells by KvLQT1 might be a possible mechanism to affect insulin-secretory functions.

We confirmed that rs13266634 in SLC30A8 has nominal association with the risk of T2DM (adjusted $p=0.045$ ), while there were no significant relationships among rs4402960 (IGF2BP2), rs8050136 (FTO), rs734312 (WFS1) and a predisposition for T2DM (adjusted $p=0.123,0.347$ and 0.362 , respectively). Several reports have demonstrated that not only the rs1111875 (Pascoe et al. 2007) and rs10811661 (Horikoshi et al. 2007) SNPs, but also the risk allele of SLC30A8, rs13266634 are associated with reduced insulin-secretory function (Staiger et al. 2007; Steinthorsdottir et al. 2007; Boesgaard et al. 2008; Cauchi et al. 2008; Kang et al. 2008b). Since early beta cell secretory defects are more important predisposing factors to T2DM than insulin resistance in various Asian populations (Fukushima et al. 2004; Yoon et al. 2003), dysfunction of genes related to insulin secretion may play an essential role in the development of T2DM in Korean adults, supported by our findings that genetic variants in the $S L C 30 A 8$ or $C D K N 2 A / B$, not obesity genes such as FTO, showed a statistical association with T2DM. The SLC30A8 gene encodes ZnT-8, a novel member of the cation diffusion facilitator family, exclusively expressed in pancreatic beta cells (Chimienti et al. 2006). ZnT-8 is thought to be a key protein for insulin secretion by regulating the homeostasis of zinc, which is known as an essential metal ion for insulin storage and secretion into intracellular vesicles (Chausmer 1998). Because the rs13266634 SNP causes an amino acid change (R325 W) in the intracellular C-terminus of the $\mathrm{ZnT}-8$ protein, this single nucleotide substitution might act as a gain-of-function mutation that increases protein translation efficiency or modifies the posttranslational structure, thereby enhancing the beta cell secretory functions.

There were some limitations in this study. First, we did not analyze the association between the candidate SNPs and indices of beta cell secretory functions or insulin resistance due to a lack of data. Second, not all proven T2DM susceptibility genes were examined because of the low frequency of risk alleles (data not shown) in our population. For example, TCF7L2, one of the most promising T2DM susceptibility genes in other studies, showed an MAF of only $5.4 \%$ in our previous study (Kang et al. 2008a). The estimated powers of our study were 40.2, 76.1, $60.7,35.7,48.5,24.7,35.9$ and $98.6 \%$ for $\mathrm{rs} 13266634$ (SLC30A8), rs1111875 (HHEX), rs10811661 (CDKN2A/B), rs4402960 (IGF2BP2), $\quad$ rs8050136 (FTO), $\quad$ rs734312 
(WFS1), rs7754840 (CDKAL1) and rs2237892 (KCNQ1), respectively, based on the reference ORs and allele frequencies from an Asian population (for rs1111875 and rs2237892 only) (Omori et al. 2008; Yasuda et al. 2008) and European populations (for other SNPs) (Frayling 2007). Much larger numbers of subjects are required to replicate previous studies with high power.

In conclusion, we have confirmed that there are significant associations between SNPs within the HHEX, $C D K N 2 A / B, C D K A L 1$ and $K C N Q 1$ genes and T2DM in the Korean population. To further confirm this association, additional studies are needed to elucidate the functional mechanism of these SNPs and to analyze the association between these polymorphisms and T2DM in other populations.

Acknowledgments This study was supported by the Global 5-5-10 Project, Yonsei University (6-2007-0087), and funds from the Department of Internal Medicine in Yonsei Medical University (2008) and the Memorial Foundation of Kim Myoung Sun (2008).

\section{References}

Altshuler D, Hirschhorn JN, Klannemark M, Lindgren CM, Vohl MC, Nemesh J, Lane CR, Schaffner SF, Bolk S, Brewer C, Tuomi T, Gaudet D, Hudson TJ, Daly M, Groop L, Lander ES (2000) The common PPARgamma Pro12Ala polymorphism is associated with decreased risk of type 2 diabetes. Nat Genet 26:76-80

Boesgaard TW, Zilinskaite J, Vanttinen M, Laakso M, Jansson PA, Hammarstedt A, Smith U, Stefan N, Fritsche A, Haring H, Hribal M, Sesti G, Zobel DP, Pedersen O, Hansen T (2008) The common SLC30A8 Arg325Trp variant is associated with reduced first-phase insulin release in 846 non-diabetic offspring of type 2 diabetes patients-the EUGENE2 study. Diabetologia 51:816-820

Cauchi S, Proença C, Choquet H, Gaget S, De Graeve F, Marre M, Balkau B, Tichet J, Meyre D, Vaxillaire M, Froguel P (2008) Analysis of novel risk loci for type 2 diabetes in a general French population: the D.E.S.I.R. study. J Mol Med 86:341-348

Chausmer AB (1998) Zinc, insulin and diabetes. J Am Coll Nutr 17:109-115

Chen YH, Guh JY, Chuang TD, Chen HC, Chiou SJ, Huang JS, Yang YL, Chuang LY (2007) High glucose decreases endothelial cell proliferation via the extracellular signal regulated kinase/ p15(INK4b) pathway. Arch Biochem Biophys 465:164-171

Chimienti F, Devergnas S, Pattou F, Schuit F, Garcia-Cuenca R, Vandewalle B, Kerr-Conte J, Van Lommel L, Grunwald D, Favier A, Seve M (2006) In vivo expression and functional characterization of the zinc transporter ZnT8 in glucose-induced insulin secretion. J Cell Sci 119:4199-4206

Foley AC, Mercola M (2005) Heart induction by Wnt antagonists depends on the homeodomain transcription factor Hex. Genes Dev 19:387-396

Frayling TM (2007) Genome-wide association studies provide new insights into type 2 diabetes aetiology. Nat Rev Genet 8:657-662

Fukushima M, Suzuki H, Seino Y (2004) Insulin secretion capacity in the development from normal glucose tolerance to type 2 diabetes. Diabetes Res Clin Pract 66(Suppl 1):S37-S43

Furukawa Y, Shimada T, Furuta H, Matsuno S, Kusuyama A, Doi A, Nishi M, Sasaki H, Sanke T, Nanjo K (2008) Polymorphisms in the IDE-KIF11-HHEX gene locus are reproducibly associated with type 2 diabetes in a Japanese population. J Clin Endocrinol Metab 93:310-314

Gloyn AL, Weedon MN, Owen KR, Turner MJ, Knight BA, Hitman G, Walker M, Levy JC, Sampson M, Halford S, McCarthy MI, Hattersley AT, Frayling TM (2003) Large-scale association studies of variants in genes encoding the pancreatic beta-cell KATP channel subunits Kir6.2 (KCNJ11) and SUR1 (ABCC8) confirm that the KCNJ11 E23 K variant is associated with type 2 diabetes. Diabetes 52:568-572

Grant SF, Thorleifsson G, Reynisdottir I, Benediktsson R, Manolescu A, Sainz J, Helgason A, Stefansson H, Emilsson V, Helgadottir A, Styrkarsdottir U, Magnusson KP, Walters GB, Palsdottir E, Jonsdottir T, Gudmundsdottir T, Gylfason A, Saemundsdottir J, Wilensky RL, Reilly MP, Rader DJ, Bagger Y, Christiansen C, Gudnason V, Sigurdsson G, Thorsteinsdottir U, Gulcher JR, Kong A, Stefansson K (2006) Variant of transcription factor 7-like 2 (TCF7L2) gene confers risk of type 2 diabetes. Nat Genet 38:320-323

Hanis CL, Boerwinkle E, Chakraborty R, Ellsworth DL, Concannon P, Stirling B, Morrison VA, Wapelhorst B, Spielman RS, Gogolin-Ewens KJ, Shepard JM, Williams SR, Risch N, Hinds D, Iwasaki N, Ogata M, Omori Y, Petzold C, Rietzch H, Schroder HE, Schulze J, Cox NJ, Menzel S, Boriraj VV, Chen X, Lim LR, Lindner T, Mereu LE, Wang YQ, Xiang K, Yamagata K, Yang Y, Bell GI (1996) A genome-wide search for human non-insulin-dependent (type 2) diabetes genes reveals a major susceptibility locus on chromosome 2 . Nat Genet 13:161-166

Horikoshi M, Hara K, Ito C, Shojima N, Nagai R, Ueki K, Froguel P, Kadowaki T (2007) Variations in the HHEX gene are associated with increased risk of type 2 diabetes in the Japanese population. Diabetologia 50:2461-2466

Kang ES, Kim MS, Kim YS, Hur KY, Han SJ, Nam CM, Ahn CW, Cha BS, Kim SI, Lee HC (2008a) A variant of the transcription factor 7-like 2 (TCF7L2) gene and the risk of posttransplantation diabetes mellitus in renal allograft recipients. Diabetes care 31:63-68

Kang ES, Kim MS, Kim YS, Kim CH, Han SJ, Chun SW, Hur KY, Nam CM, Ahn CW, Cha BS, Kim SI, Lee HC (2008b) A polymorphism in the zinc transporter gene SLC30A8 confers resistance against posttransplantation diabetes mellitus in renal allograft recipients. Diabetes 57:1043-1047

Kim WY, Sharpless NE (2006) The regulation of INK4/ARF in cancer and aging. Cell 127:265-275

McLin VA, Rankin SA, Zorn AM (2007) Repression of Wnt/betacatenin signaling in the anterior endoderm is essential for liver and pancreas development. Development 134:2207-2217

Ng MC, Park KS, Oh B, Tam CH, Cho YM, Shin HD, Lam VK, Ma RC, So WY, Cho YS, Kim HL, Lee HK, Chan JC, Cho NH (2008) Implication of Genetic Variants near TCF7L2, SLC30A8, HHEX, CDKAL1, CDKN2A/B, IGF2BP2 and FTO in Type 2 Diabetes and Obesity in 6719 Asians. Diabetes 57:2226-2233

Omori S, Tanaka Y, Takahashi A, Hirose H, Kashiwagi A, Kaku K, Kawamori R, Nakamura Y, Maeda S (2008) Association of CDKAL1, IGF2BP2, CDKN2A/B, HHEX, SLC30A8, and KCNJ11 with susceptibility to type 2 diabetes in a Japanese population. Diabetes 57:791-795

Palmer ND, Goodarzi MO, Langefeld CD, Ziegler J, Norris JM, Haffner SM, Bryer-Ash M, Bergman RN, Wagenknecht LE, Taylor KD, Rotter JI, Bowden DW (2008) Quantitative trait analysis of T2D susceptibility loci identified from whole genome association studies in the IRAS family study. Diabetes 57:10931100

Pascoe L, Tura A, Patel SK, Ibrahim IM, Ferrannini E, Zeggini E, Weedon MN, Mari A, Hattersley AT, McCarthy MI, Frayling TM, Walker M (2007) Common variants of the novel type 2 
diabetes genes CDKAL1 and HHEX/IDE are associated with decreased pancreatic beta-cell function. Diabetes 56:3101-3104 Sandhu MS, Weedon MN, Fawcett KA, Wasson J, Debenham SL, Daly A, Lango H, Frayling TM, Neumann RJ, Sherva R, Blech I, Pharoah PD, Palmer CN, Kimber C, Tavendale R, Morris AD, McCarthy MI, Walker M, Hitman G, Glaser B, Permutt MA, Hattersley AT, Wareham NJ, Barroso I (2007) Common variants in WFS1 confer risk of type 2 diabetes. Nat Genet 39:951-953

Saxena R, Voight BF, Lyssenko V, Burtt NP, de Bakker PI, Chen H, Roix JJ, Kathiresan S, Hirschhorn JN, Daly MJ, Hughes TE, Groop L, Altshuler D, Almgren P, Florez JC, Meyer J, Ardlie K, Bengtsson Boström K, Isomaa B, Lettre G, Lindblad U, Lyon HN, Melander O, Newton-Cheh C, Nilsson P, Orho-Melander M, Råstam L, Speliotes EK, Taskinen MR, Tuomi T, Guiducci C, Berglund A, Carlson J, Gianniny L, Hackett R, Hall L, Holmkvist J, Laurila E, Sjögren M, Sterner M, Surti A, Svensson M, Svensson M, Tewhey R, Blumenstiel B, Parkin M, Defelice M, Barry R, Brodeur W, Camarata J, Chia N, Fava M, Gibbons J, Handsaker B, Healy C, Nguyen K, Gates C, Sougnez C, Gage D, Nizzari M, Gabriel SB, Chirn GW, Ma Q, Parikh H, Richardson D, Ricke D, Purcell S (2007) Genome-wide association analysis identifies loci for type 2 diabetes and triglyceride levels. Science 316:1331-1336

Scott LJ, Mohlke KL, Bonnycastle LL, Willer CJ, Li Y, Duren WL, Erdos MR, Stringham HM, Chines PS, Jackson AU, ProkuninaOlsson L, Ding CJ, Swift AJ, Narisu N, Hu T, Pruim R, Xiao R, Li XY, Conneely KN, Riebow NL, Sprau AG, Tong M, White PP, Hetrick KN, Barnhart MW, Bark CW, Goldstein JL, Watkins L, Xiang F, Saramies J, Buchanan TA, Watanabe RM, Valle TT, Kinnunen L, Abecasis GR, Pugh EW, Doheny KF, Bergman RN, Tuomilehto J, Collins FS, Boehnke M (2007) A genome-wide association study of type 2 diabetes in Finns detects multiple susceptibility variants. Science 316:1341-1345

Sladek R, Rocheleau G, Rung J, Dina C, Shen L, Serre D, Boutin P, Vincent D, Belisle A, Hadjadj S, Balkau B, Heude B, Charpentier G, Hudson TJ, Montpetit A, Pshezhetsky AV, Prentki M, Posner BI, Balding DJ, Meyre D, Polychronakos C, Froguel P (2007) A genome-wide association study identifies novel risk loci for type 2 diabetes. Nature 445:881-885

Staiger H, Machicao F, Stefan N, Tschritter O, Thamer C, Kantartzis K, Schäfer SA, Kirchhoff K, Fritsche A, Häring HU (2007) Polymorphisms within novel risk loci for type 2 diabetes determine beta-cell function. PLOS One 2:e832

Steinthorsdottir V, Thorleifsson G, Reynisdottir I, Benediktsson R, Jonsdottir T, Walters GB, Styrkarsdottir U, Gretarsdottir S,
Emilsson V, Ghosh S, Baker A, Snorradottir S, Bjarnason H, Ng MC, Hansen T, Bagger Y, Wilensky RL, Reilly MP, Adeyemo A, Chen Y, Zhou J, Gudnason V, Chen G, Huang H, Lashley K, Doumatey A, So WY, Ma RC, Andersen G, Borch-Johnsen K, Jorgensen T, van Vliet-Ostaptchouk JV, Hofker MH, Wijmenga C, Christiansen C, Rader DJ, Rotimi C, Gurney M, Chan JC, Pedersen O, Sigurdsson G, Gulcher JR, Thorsteinsdottir U, Kong A, Stefansson K (2007) A variant in CDKAL1 influences insulin response and risk of type 2 diabetes. Nat Genet 39:770-775

Ubeda M, Rukstalis JM, Habener JF (2006) Inhibition of cyclindependent kinase 5 activity protects pancreatic beta cells from glucotoxicity. J Biol Chem 281:28858-28864

Wei FY, Nagashima K, Ohshima T, Saheki Y, Lu YF, Matsushita M, Yamada Y, Mikoshiba K, Seino Y, Matsui H, Tomizawa K (2005) Cdk5-dependent regulation of glucose-stimulated insulin secretion. Nature Med 11:1104-1108

Yasuda K, Miyake K, Horikawa Y, Hara K, Osawa H, Furuta H, Hirota Y, Mori H, Jonsson A, Sato Y, Yamagata K, Hinokio Y, Wang HY, Tanahashi T, Nakamura N, Oka Y, Iwasaki N, Iwamoto Y, Yamada Y, Seino Y, Maegawa H, Kashiwagi A, Takeda J, Maeda E, Shin HD, Cho YM, Park KS, Lee HK, Ng MC, Ma RC, So WY, Chan JC, Lyssenko V, Tuomi T, Nilsson P, Groop L, Kamatani N, Sekine A, Nakamura Y, Yamamoto K, Yoshida T, Tokunaga K, Itakura M, Makino H, Nanjo K, Kadowaki T, Kasuga M (2008) Variants in KCNQ1 are associated with susceptibility to type 2 diabetes mellitus. Nat Genet (in press) PMID: 18711367

Yoon KH, Ko SH, Cho JH, Lee JM, Ahn YB, Song KH, Yoo SJ, Kang MI, Cha BY, Lee KW, Son HY, Kang SK, Kim HS, Lee IK, Bonner-Weir S (2003) Selective beta-cell loss and alpha-cell expansion in patients with type 2 diabetes mellitus in Korea. J Clin Endocrinol Metab 88:2300-2308

Zeggini E, Weedon MN, Lindgren CM, Frayling TM, Elliott KS, Lango H, Timpson NJ, Perry JR, Rayner NW, Freathy RM, Barrett JC, Shields B, Morris AP, Ellard S, Groves CJ, Harries LW, Marchini JL, Owen KR, Knight B, Cardon LR, Walker M, Hitman GA, Morris AD, Doney AS, McCarthy MI, Hattersley AT (2007) Replication of genome-wide association signals in UK samples reveals risk loci for type 2 diabetes. Science 316:1336-1341

Zimmet P, Shaw J, Alberti KG (2003) Preventing Type 2 diabetes and the dysmetabolic syndrome in the real world: a realistic view. Diabet Med 20:693-702 